\title{
LIGAÇÕES EM ESTRUTURAS DE AÇO UTILIZANDO EMENDAS COM PARAFUSOS DE ALTA RESISTÊNCIA SOLICITADAS NA FLEXÃO SIMPLES
}

\section{Connections in steel structures using emendations with high strength screws requested in simple bending}

\author{
Ronivon Soares Pereira ${ }^{1}$, Orlano Ferreira Gomes ${ }^{2}$
}

Recebido em 07 de novembro de 2013; recebido para revisão em 10 de dezembro de 2013; aceito em 17 de abril de 2014; disponível on-line em 22 de maio de 2014.

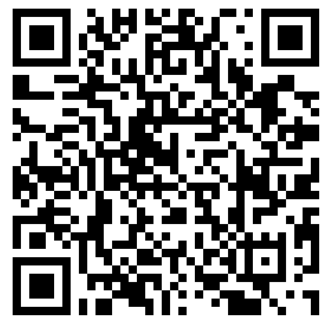

PALAVRAS CHAVE:

Aço;

Parafusos;

Estruturas de aço;

Flexão simples.

Keywords:

Steel;

Bolts;

Steel structures;

Simple bending

* Contato com o autor:

1 e-mail : ronivon.sp@gmail.com

Civil, Universidade Federal de Goiás (EEC/UFG).

${ }^{2}$ e-mail : orlandoferreirag0@gmail.com (O. F. Gomes)

Professor Doutor da Escola de Engenharia Civil, Universidade Federal de Goiás (EEC/UFG).

ISSN: 2179-0612

(C) 2014 REEC - Todos os direitos reservados.

\section{INTRODUÇÃO}

Quando se depara com estruturas metálicas de grande porte como torres de transmissão de energia, pontes metálicas, edifícios de múltiplos andares em aço, hangares e outras construções em que se utiliza a estrutura metálica, todas estas obras não poderiam ter um bom desempenho se não fossem a qualidade do projeto, dos materiais envolvidos, dos processos de fabricação e montagem, inspeção e manutenção.

As estruturas metálicas, principalmente as de perfis tipo I laminados de abas paralelas dependem do controle de qualidade em suas emendas parafusadas. Por isso a importância de se estudar este tema, pois tal estudo tem o intuito de 
fornecer uma contribuição fundamental para os projetistas, fabricantes e montadores de estruturas metálicas que precisam fazer com que seu produto possa competir com este mercado cada vez mais globalizado e exigente, de forma segura e econômica.

Este artigo tem por objetivo analisar a capacidade resistente de vigas bi apoiadas em aço constituídas de perfis tipo I laminados de abas paralelas com dois eixos de simetria, sendo dotadas de emendas com parafusos de alta resistência, estando estes modelos solicitados por esforços de flexão simples.

\section{REVISÃO BIBLIOGRÁFICA}

\subsection{PERFIS LAMINADOS A QUENTE}

De acordo com Pfeil (2009) laminação é o processo pela qual o aço é transformado nos principais produtos siderúrgicos utilizados nas estruturas da construção civil, podem ser chapas e perfis laminados. Placas de aço são aquecidas ao rubro e introduzidas nos laminadores desbastadores, são utilizados dois rolos giratórios para comprimir a placa de aço, desta forma a placa reduz a seção e aumenta o seu comprimento. Este processo é feito varias vezes no laminador, nas quais a distancia entre os rolos é reduzida progressivamente. Em sequencia, o aço que passa no laminador desbastador, é enviado para o laminador que dá a característica dos produtos siderúrgicos utilizados na indústria da construção civil.

Por meio dos processos de produção industrial dos perfis de aço consequentemente as tensões residuais representam um estado de tensões internas auto-equilibrado nos perfis de aço. Segundo Gomes (2006), as imperfeições mecânicas ou físicas contidas nos perfis de aço procedem substancialmente devido à: presença das tensões residuais; distribuição não homogênea das características mecânicas através da seção transversal.

O detalhamento do processo de resfriamento de perfil I laminado a quente mostrado na (Figura 1a), a temperatura ao final da laminação (To) é igual a $600^{\circ} \mathrm{C}$. As partes mais expostas resfriam mais rapidamente do que as outras partes, numa fase intermediária do resfriamento (T1), uma distribuição tensão residual longitudinal surge (Figura 1b). Neste ponto, as áreas mornas sofrem deformação plástica devido à tensão de compressão onde resfriaram mais rapidamente. Isso reduz a tensão residual induzida, (Figura 1c) para a temperatura intermediária (T2). Consequentemente, uma vez o resfriamento esteja completo, as áreas, que primeiro se resfriaram estarão comprimidas, enquanto que as áreas que se resfriaram por últimos estarão tracionadas, (Figura 1d).

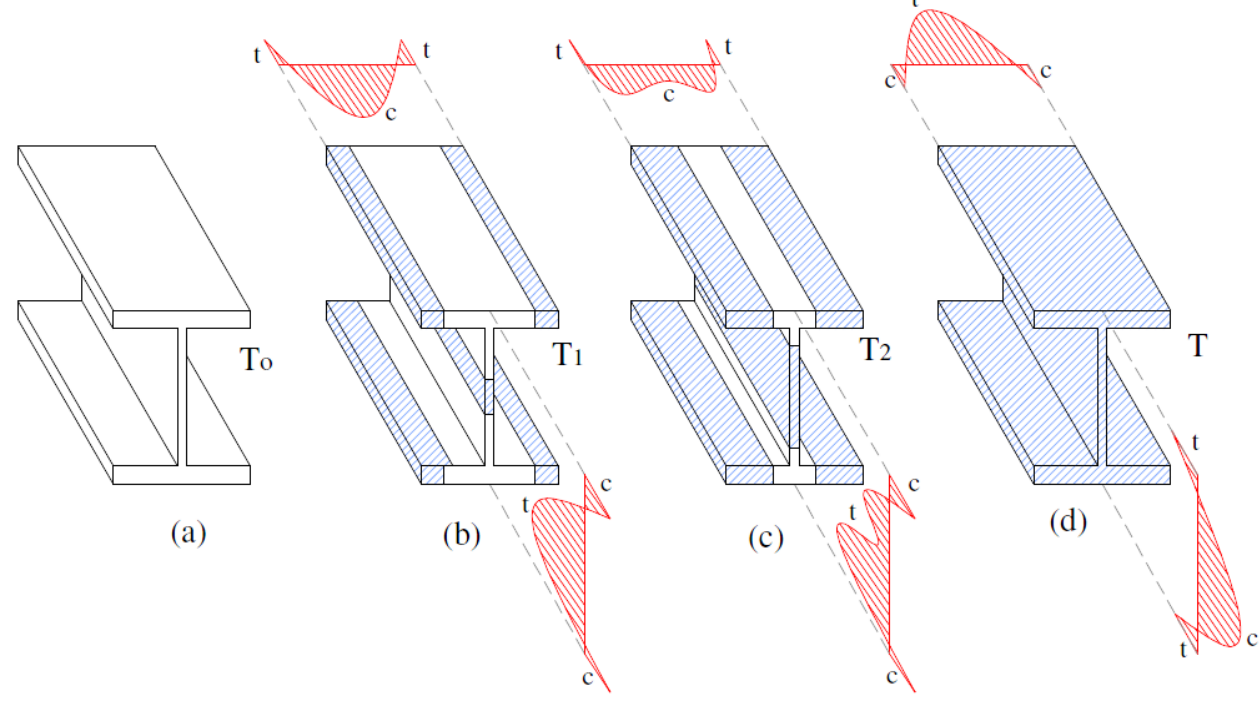

Figura 1: Processo de resfriamento de um perfil I laminado a quente Fonte: Gomes (2006). 
Os aços microligados, pela qual consistem os perfis laminados de abas paralelas ASTM A-572 (aços de alta resistência mecânica e baixa liga) utilizam vários elementos de liga em adição ao carbono para que possam atingir resistências mecânicas superiores; o limite de escoamento para estes aços está situado entre 290 e $450 \mathrm{MPa}$ e resistência a tração de $450 \mathrm{MPa}$ de com a NBR 7007 (ABNT 2011) e a norma americana ASTM A-572/50 (2006).

\subsection{MODOS DE RUPTURA EM VIGAS SUBMETIDAS À FLEXÃO}

Como descrito por Pfeil (2009) as flambagens podem ser: flambagem local é a perda de estabilidade das chapas comprimidas componentes do perfil, a qual reduz o momento resistente da seção; flambagem global a viga perda da estabilidade no plano principal da flexão, em geral na vertical, passando a apresentar deslocamentos laterais e rotações de torção. Para evitar a flambagem de uma viga I, onde a rigidez à torção é muito pequena, é preciso prover contenção lateral à viga.

A NBR 8800 (ABNT 2008) tem como característica para cálculos que devem ser considerados estados limites últimos, flambagem lateral com torção (FLT), flambagem local da mesa comprimida (FLM) e flambagem local da alma (FLA).

Um dos modos de ruptura de uma viga pode ser a flambagem local da mesa comprimida, segundo Pfeil (2009) este tipo de ruptura em vigas I fletidas no plano da alma, indica que as tensões normais de compressão da mesa (? (? ${ }_{\mathrm{bc}}$ ) variam entre um valor máximo sobre a alma e um valor mínimo na borda. A flambagem local da alma pode transferir tensões para a mesa comprimida, reduzindo o momento resistente e tendo como colapso a alma da viga.

Ainda segundo Pfeil (2009) o fenômeno da flambagem lateral por torção pode ser entendido a partir da flambagem por flexão de uma coluna. A seção composta da mesa superior e de um pequeno trecho da alma funciona como uma coluna entre pontos de apoio lateral, podendo flambar. Como a mesa tracionada é estabilizada pelas tensões de tração, ela dificulta o deslocamento lateral da mesa comprimida, de modo que o fenômeno se processa como torção da viga. Sob efeito de torção as seções sofrem rotações acompanhadas de deformações longitudinais, causando o empenamento. Uma seção originalmente plana se deforma deixando de ser plana.

\subsection{LIGAÇÕES COM PARAFUSOS EM PEÇAS METÁLICAS}

Ao analisar diferentes trabalhos científicos na área de estruturas, percebem-se estudos abrangentes dos elementos de estruturas de aço, buscando entender os fundamentos teóricos e as correspondentes adaptações que deram origem às prescrições contidas nas normas técnicas utilizadas para dimensionamento de estruturas metálicas.

A pesquisa de Valenciani (1997) sobre ligações em estruturas de aço descreve os alguns dispositivos de ligação, apresentando o comportamento estrutural de parafusos e a avaliação da resistência, enfatizando os tipos e as características estruturais dos conectores.

Valenciani (1997) diz que as ligações em estruturas metálicas são constituídas por dois tipos de componentes, a saber: a) os elementos de ligação, que são componentes que facilitam ou que permitem a transmissão dos esforços gerados na estrutura, como enrijecedores, as chapas de nó, entre outros e b) os dispositivos de ligação, que são os componentes que proporcionam a união entre os elementos de ligação e as partes da estrutura que se deseja conectar, sendo que dentre estes componentes têm-se as soldas e os conectores.

Um fator importante para uma conexão perfeita da ligação estrutural é o perfil das roscas e suas tolerâncias de fabricação, tanto para parafusos de alta resistência quanto para parafusos comuns. Segundo Valenciani (1997) os parafusos estruturais se dividem em parafusos comuns e parafusos de alta resistência. O parafuso comum, de qualidade estrutural, mais utilizado é o ASTM A307. Esses parafusos são feitos de aço de baixo carbono com uma mínima resistência à tração de $415 \mathrm{MPa}$. 
Os parafusos ASTM A325 são parafusos de aço de médio carbono com tratamento térmico com alta resistência para ligações com aço estrutural, tendo um limite de escoamento de aproximadamente 560 a $630 \mathrm{MPa}$. Já os parafusos ASTM A490 são de aço-liga tratado termicamente, com um limite de escoamento de aproximadamente 790 a $900 \mathrm{MPa}$, dependendo do diâmetro. A Figura 2 mostra a identificação dos parafusos A325 e A490.

Componentes complementares como as porcas de aços compatíveis ASTM A563 e arruelas ASTM F436 são normalmente especificadas incluindo a resistência ao desgaste por intempéries.

De acordo com Valenciani (1997), parafusos ASTM A449 são indicados onde a força é transmitida pelo atrito mobilizado entre as chapas (Figura 3) ou onde a força é transmitida pelo contato do corpo do parafuso com a parede do furo (Figura 4). Os parafusos ASTM A449 são parafusos de aço carbono temperados e podem ser galvanizados a quente. Eles são ocasionalmente usados quando são necessários diâmetros acima de 38 até $76 \mathrm{~mm}$ ( $11 / 2$ até $\left.3^{\prime \prime}\right)$.

De acordo com RCSC (2009) quando ambas as forças atuar nas chapas de ligação sobre um parafuso, surgirá tensão de cisalhamento, e a interação pode ser convenientemente expressa como uma solução elíptica, que inclui os elementos do parafuso sobre tensão de cisalhamento com atuação de tensão no parafuso.

Ainda segundo Valenciani (1997) nas ligações parafusadas, cuja força resultante é perpendicular ao eixo dos parafusos, a transmissão desta força ocorre por meio de dois mecanismos: o atrito mobilizado entre as partes e o contato do corpo dos parafusos nos respectivos furos.

Analisando o comportamento resistente de uma conexão com vários parafusos alinhados (Figura 5), submetida a um carregamento crescente, observa-se os seguintes estágios de comportamento: a) inicialmente a força é transmitida pelo atrito mobilizado nas extremidades, não havendo deslizamentos (Figura $5 a)$; b) quando o atrito nas extremidades é vencido, ocorre o contato destes parafusos extremos na parede dos furos (Figura 5b); c) aumentando-se a força, a zona de deslizamento caminha para a porção central da conexão, até que a resistência global ao atrito seja vencida (Figura $5 c$ ) e; d) na sequencia, os parafusos e o metal base das extremidades vão sofrendo elevadas deformações e consequentemente atingindo a plastificação, conforme mostra as forças cortantes apresentadas nos gráficos da Figura $5 \mathrm{~d}$.

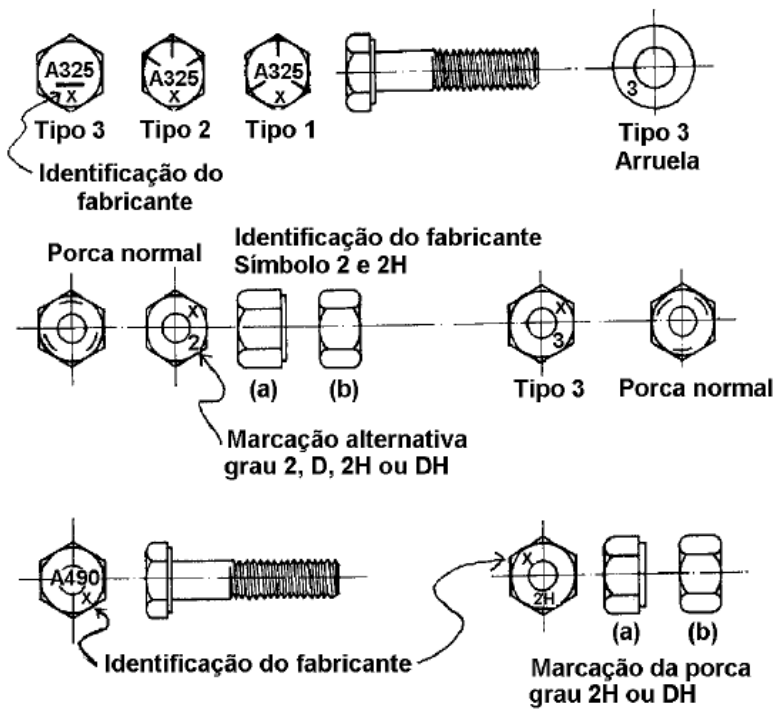

Figura 2: Identificação dos parafusos A-325 e A-490

Fonte: Valenciani (1997). 


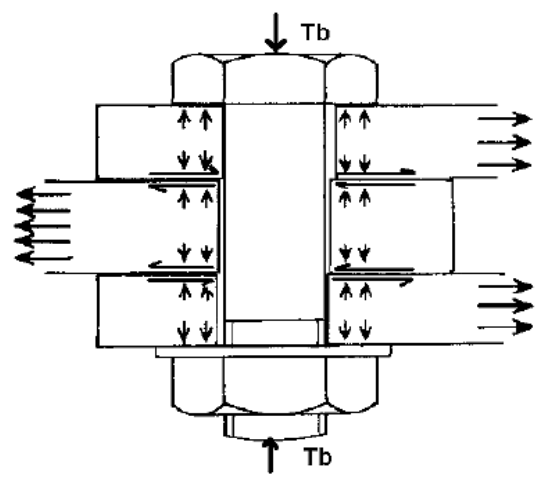

Figura 3: Transmissão de esforços por atrito Fonte: Valenciani (1997).

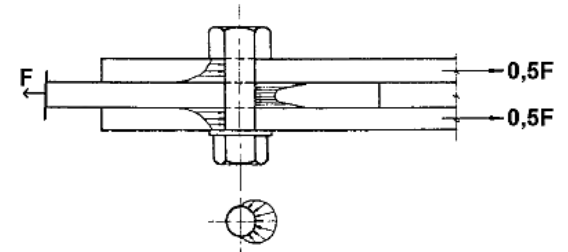

(a) Distribuição real das tensões

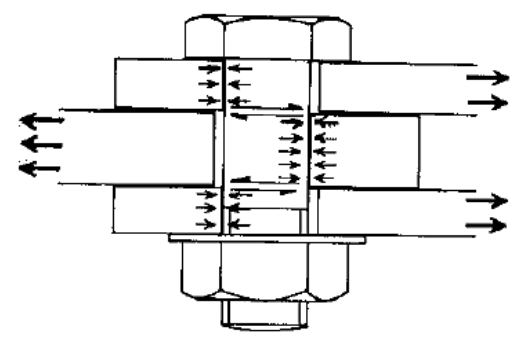

(b) Distribuição admitida para cálculo

Figura 4: Transmissão de esforços por contato

Fonte: Valenciani (1997).

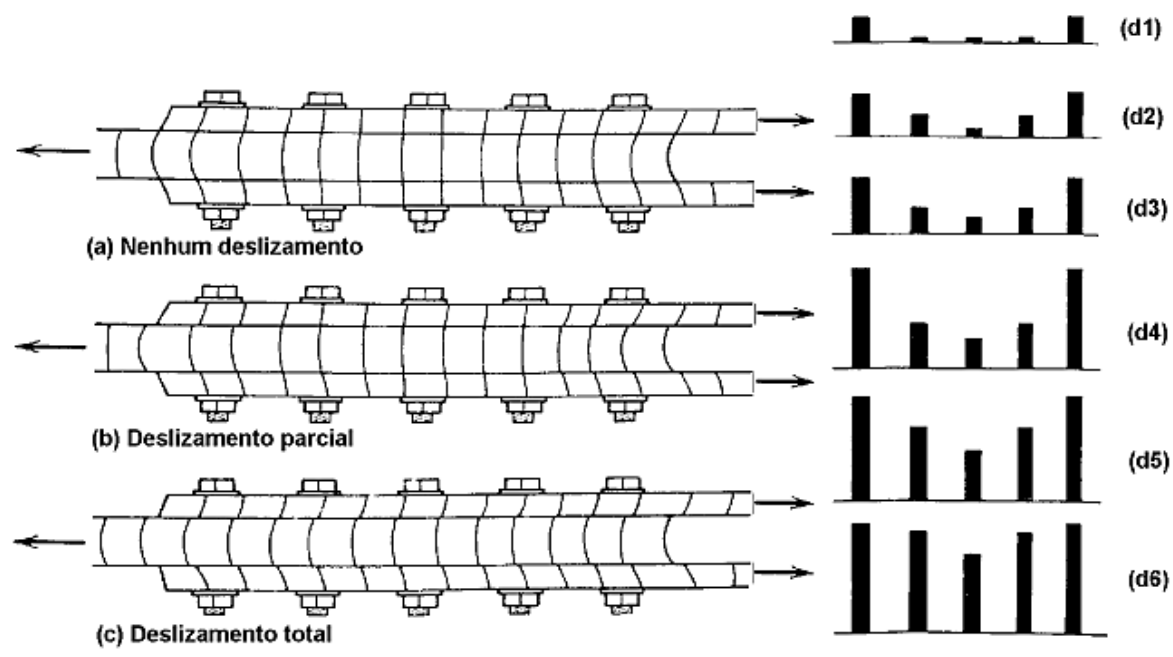

(d)

Figura 5 (a), (b), (c): Representação esquemática de três estágios de carregamento numa conexão parafusada; (d1) a (d6) força cortante nos parafusos em função do estágio de carregamento.

Fonte: Valenciani (1997). 
Valenciani (1997) concluiu que de nada adianta projetar adequadamente as barras de uma estrutura se suas ligações são projetadas de maneira inadequada. Além de ressaltar que um projeto adequado de uma ligação consiste não somente na análise estrutural, mas também, na análise de viabilidade técnico-econômica da utilização de um determinado dispositivo de ligação e do respectivo detalhe construtivo.

\subsection{ESTUDO DE LIGAÇÕES PARAFUSADAS E SOLDADAS}

O estudo de Silva (2006) constituiu na realização de quatro ensaios em quatro diferentes configurações de ligações viga-coluna, agrupadas em dois grupos: sem enrijecedores e com enrijecedores de alma soldados nos flanges da coluna, estabelecendo assim parâmetros de comparação; além de diferir também as espessuras das vigas.

O esquema de montagem estabeleceu-se com a instalação de três pórticos de reação paralelamente entre si sendo equidistantes de $1,0 \mathrm{~m}$ entre seus planos centrais. Foram instalados dois acessórios de montagem, sendo um a placa de base e o outro a placa de topo. O primeiro foi parafusado junto à laje de reação, ao passo que o segundo foi parafusado no pórtico de reação conforme Figura 6.

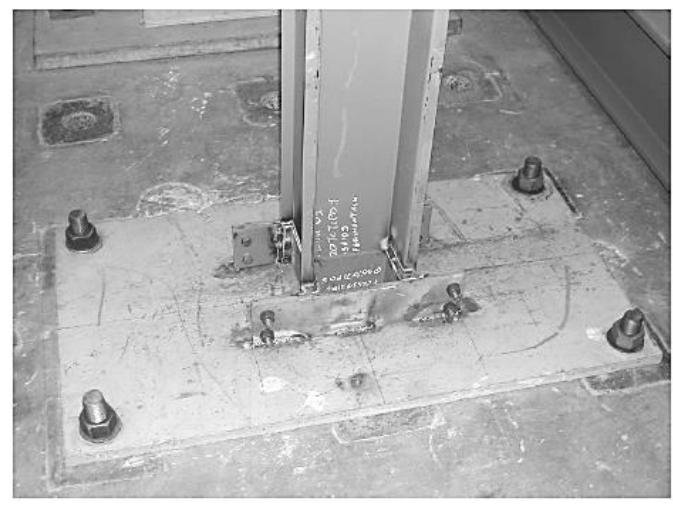

a) Placa de base
Após a fixação da coluna, a viga 01 e a viga 02 foram conectadas à mesma por meio de ligações parafusadas, entre as cantoneiras de ligação inferiores e superiores e os perfis $U$ suportes. Destaca-se a existência de solda no reforço junto à alma da coluna da viga 03 . Em seguida, em cada um dos pórticos de reação, foram instalados sistemas de aplicação de carga, assim o carregamento foi aplicado somente na viga 01 e viga 02.

Para medição de deslocamentos, foram utilizados os LVDT's (Load Variational Displacement Transducers) e os deflectômetros mecânicos, os LVDT's foram instalados nas vigas e no pórtico, os deflectômetros foram posicionados nas ligações e nas mesmas regiões dos LVDT's. Para medição de deformações específicas, foram utilizados extensômetros de resistência elétrica.

Os extensômetros foram colados próximos às ligações e mediram as deformações específicas nos flanges superiores e inferiores das vigas, nos enrijecedores e flanges da coluna e também no U Suporte.

Silva (2006) concluiu que em ligações não mistas, a tipologia apresentada se mostrou pouco resistente, quando na ausência de enrijecedores de alma soldados na região da ligação. O Protótipo sem enrijecedor mostrou claramente a baixa resistência, caracterizada pela maior concentração de tensões nos enrijecedores da coluna.

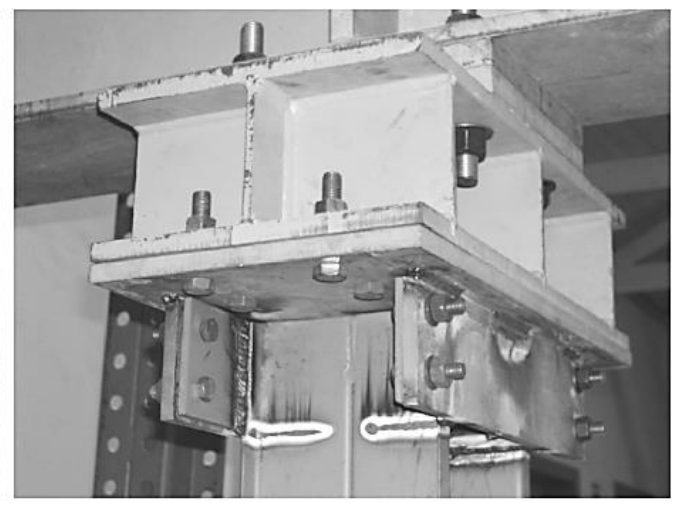

b) Placa de topo

Figura 6: Fotografias dos acessórios utilizados para fixação das colunas Fonte: Silva (2006). 
Com a utilização de enrijecedores de alma na ligação o nível de tensões nos enrijecedores da coluna, diminuiu considerávelmente e não ocorreu a plastificação. Assim a capacidade resistente da ligação e a rigidez aumentaram, e o mecanismo de colapso passou a ser o escoamento nos flanges das vigas.

A pesquisa de Almeida (2009) apresentou considerações sobre perfis formados a frio, aços patináveis, processos de soldagem e o resultado de ensaios experimentais de vigas bi-apoiadas constituídas de perfis formados a frio compostas pela junção de dois perfis $U$ enrijecidos. Constitui-se em realizar oito ensaios de vigas à flexão simples, sendo quatro vigas fabricadas com perfis produzidos com aço USI-SAC 300 e quatro vigas fabricadas com perfis produzidos com aço CSN COR 420.

O esquema de montagem do ensaio compôs-se de vigas bi-apoiadas com o comprimento total de três metros e a distância entre os dois apoios foi de 2850 mm. As vigas estiveram sujeitas à aplicação de duas forças concentradas de mesmo valor equidistantes dos apoios, posicionadas a $950 \mathrm{~mm}$ de cada apoio.

As vigas ensaiadas foram compostas de dois perfis tipo $U$ enrijecidos com união de filetes de solda nas mesas superiores e inferiores, formando uma seção dupla com alma de $200 \mathrm{~mm}$, mesa de $150 \mathrm{~mm}$, enrijecimento de $25 \mathrm{~mm}$ e enrijecedores transversais com chapa de $6,3 \mathrm{~mm}$ de espessura, localizados nas regiões de aplicação das forças e nos apoios, conforme mostra a Figura 7.
A viga foi posicionada sobre aparelhos de apoio formados por chapas metálicas e cilindros de aço simulando os apoios de $1^{\circ}$ e $2^{\circ}$ gênero.

Os deslocamentos verticais foram determinados através de deflectômetros posicionados ao longo da viga em posições prédeterminadas e as deformações obtidas através de extensômetros elétricos de resistência para aço, e ficaram devidamente posicionados na mesa inferior e na mesa superior da viga.

Com a ajuda de atuador hidráulico foi aplicado o carregamento e sua intensidade verificada por uma célula de carga posicionada entre o atuador hidráulico e a viga de reação.

Almeida (2009) concluiu que todas as vigas com emendas soldadas, fabricadas com aço CSN COR 420 tiveram resistência menor que a viga sem emenda soldada, fabricada com o mesmo tipo de aço. A viga com uma emenda soldada, fabricada com aço USI SAC 300, apresentou resistência maior que a viga sem emenda soldada.

Em média as vigas fabricadas com o aço CSN COR 420, apresentaram valores de força última de ruptura menor que os valores das vigas fabricadas com o aço USI-SAC 300.

Mesmo as vigas tendo uma pequena diferença nas propriedades geométricas em relação aos valores nominais, estas propriedades ficaram dentro do limite de tolerância, e seus resultados de resistência final na tensão de escoamento e na tensão de ruptura, tanto para as vigas de um tipo de aço USI-SAC 300 ou CSN COR 420.

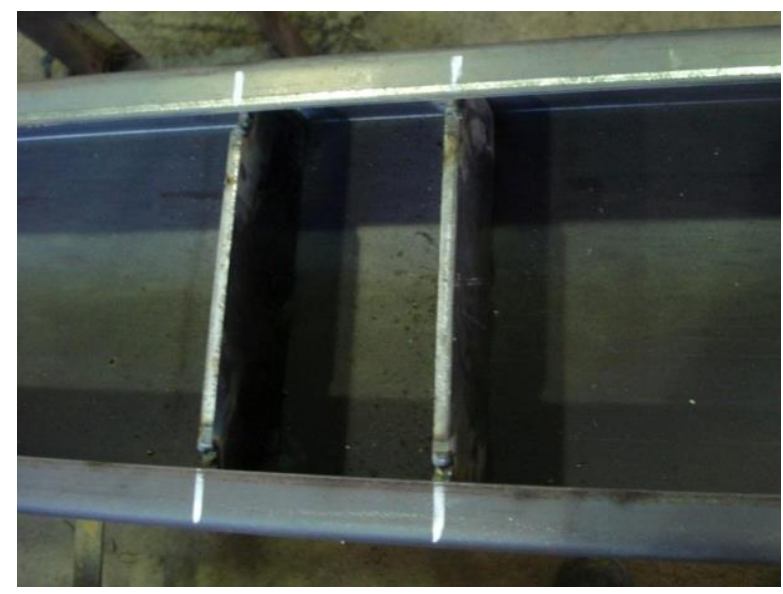

Figura 7: Fotografia do detalhe de montagem dos enrijecedores Fonte: Almeida (2009). 


\section{PROGRAMA EXPERIMENTAL}

Para o desenvolvimento desta pesquisa foram confeccionadas quatro vigas com $3000 \mathrm{~mm}$ de comprimento sendo um perfil Gerdau Aço Minas laminado com abas paralelas do tipo W $250 \times 22,3$ ASTM-A572 com altura de $250 \mathrm{~mm}$, espessura da chapa da alma de $5,8 \mathrm{~mm}$ e espessura da chapa da mesa de $6,9 \mathrm{~mm}$.

Todas as vigas utilizadas no estudo continham ligações parafusadas, ao passo que o parafuso de alta resistência utilizado foi o ASTMA325 3/4 x 2", porca sextavada 3/4" com 10 fios de rosca e arruela lisa $3 / 4 " \times 44 \times 2,0 \mathrm{~mm}$. A chapa de ligação utilizada foi uma chapa com $6,3 \mathrm{~mm}$ de espessura onde se executou furos com medidas padronizadas para fazer as emendas.

Os ensaios das vigas submetidas à flexão simples foram realizados no Laboratório de Estruturas da Escola de Engenharia Civil da Universidade Federal de Goiás (EEC/UFG).
Para determinação das propriedades mecânicas dos materiais utilizados, foram retirados corpos de prova de aço, e também foram confeccionados corpos de provas dos parafusos. Os procedimentos utilizados nos ensaios à tração estão prescritos na norma NBR 6152 (ABNT 2002) Materiais metálicos: Ensaio de tração à temperatura ambiente.

Os corpos de prova de aço foram retirados da mesa e da alma do perfil e, também, da chapa de ligação. Os corpos de prova dos parafusos foram confeccionados utilizando a cabeça do parafuso que foi retirada e abrindo rosca no local da cabeça do parafuso mantendo o seu comprimento original, e esta rosca foi fixada em duas em duas buchas, uma na parte superior e outra na parte inferior. Ambos os corpos de prova foram submetidos ao ensaio à tração. A (Figura 8) mostra os corpos de prova. A Figura 9 apresenta o corpo de prova de aço e corpo de prova do parafuso no momento do ensaio.
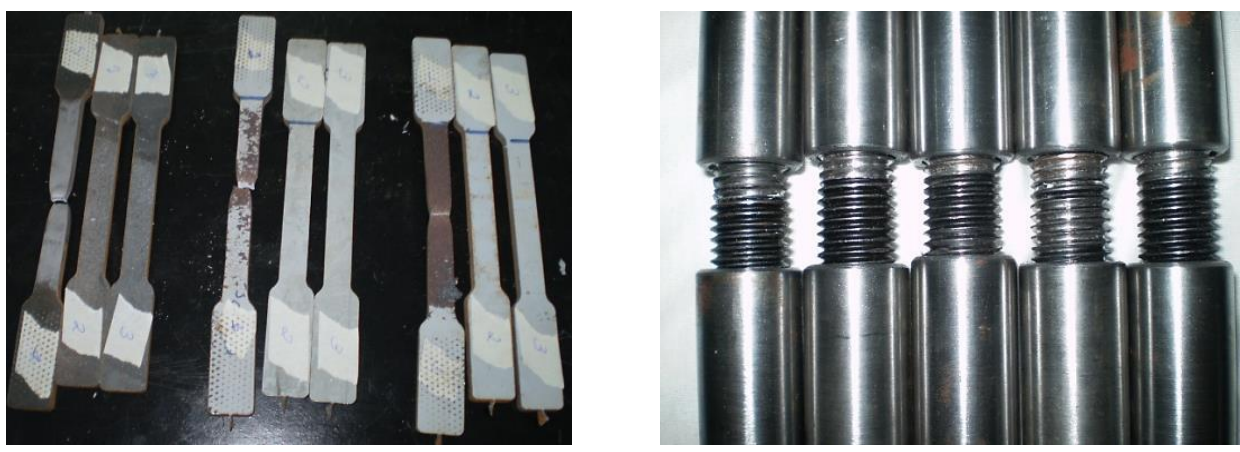

Figura 8: Corpos de prova de aço e corpos de prova dos parafusos.
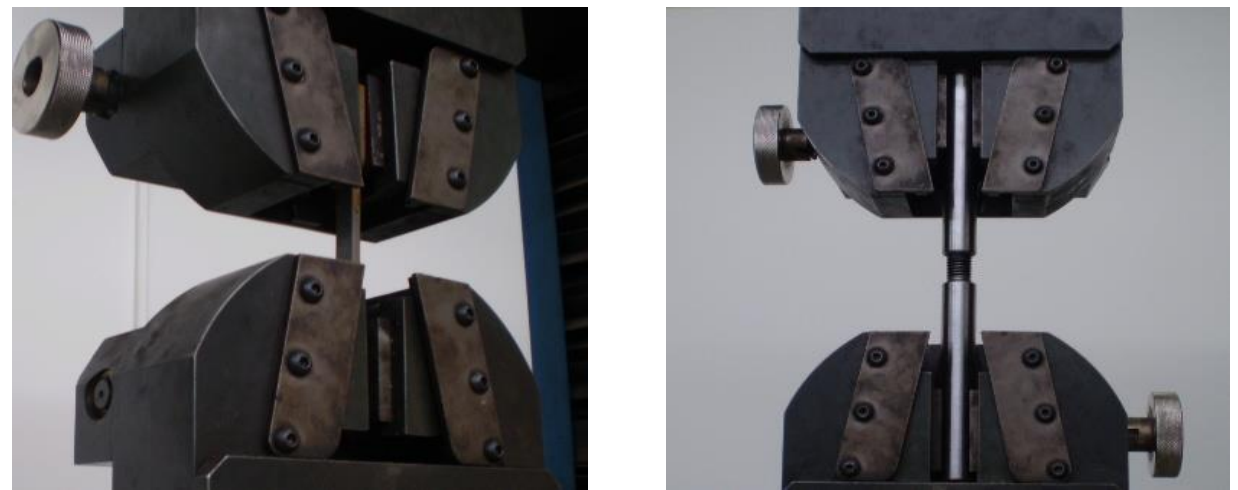

Figura 9: Corpo de prova de aço e corpo de prova do parafuso no momento do ensaio. 
A nomenclatura das vigas ensaiadas foi definida como VI-1/3D, VI-1/3E, VI-1/2SE e VI$1 / 2 C E$. Dentre as quatro vigas confeccionadas, a viga $\mathrm{VI-1/3D}$ contém uma emenda a um terço do apoio da direita, a viga VI-1/3E contém uma emenda a um terço do apoio da esquerda, a viga VI$1 / 2$ SE contém uma emenda no meio do vão e não tem enrijecedor e a viga VI-1/2CE contém uma emenda no meio do vão e tem enrijecedor nas extremidades e a $750 \mathrm{~mm}$ da extremidade da direita e a $750 \mathrm{~mm}$ da extremidade da esquerda.

A preparação das vigas para ligar uma parte na outra com a chapa de ligação e os parafusos foi possível com a utilização de um torquímetro da marca Gedore com $620 \mathrm{~mm}$ de comprimento e que mede torques de até 340 N.m. Foram utilizados extensômetros de resistência elétrica para aço da marca EXCEL que medem deformações. Os extensômetros ficaram devidamente posicionados na chapa de ligação, na mesa inferior, na mesa superior e na alma da viga como mostra a Figura 10.

As vigas foram bi-apoiadas, onde cada viga ensaiada tinha um comprimento total de $3000 \mathrm{~mm}$, foi deixada uma folga de $75 \mathrm{~mm}$ entre o eixo do apoio e a extremidade da viga, sendo assim, o vão livre entre os apoios foi de $2850 \mathrm{~mm}$. As vigas foram sujeitas à aplicação de duas forças concentradas de mesmo valor equidistantes dos apoios, posicionadas a $1220 \mathrm{~mm}$ de cada apoio. Justificou-se o fato da distância de $1220 \mathrm{~mm}$ de cada apoio ser definida, tendo em vista a padronização e a montagem de duas forças concentradas na viga que poderiam ser aplicadas em cima das emendas que estão posicionadas a um terço dos apoios. A Figura 11 mostra um sistema esquematizado de ensaio das vigas.
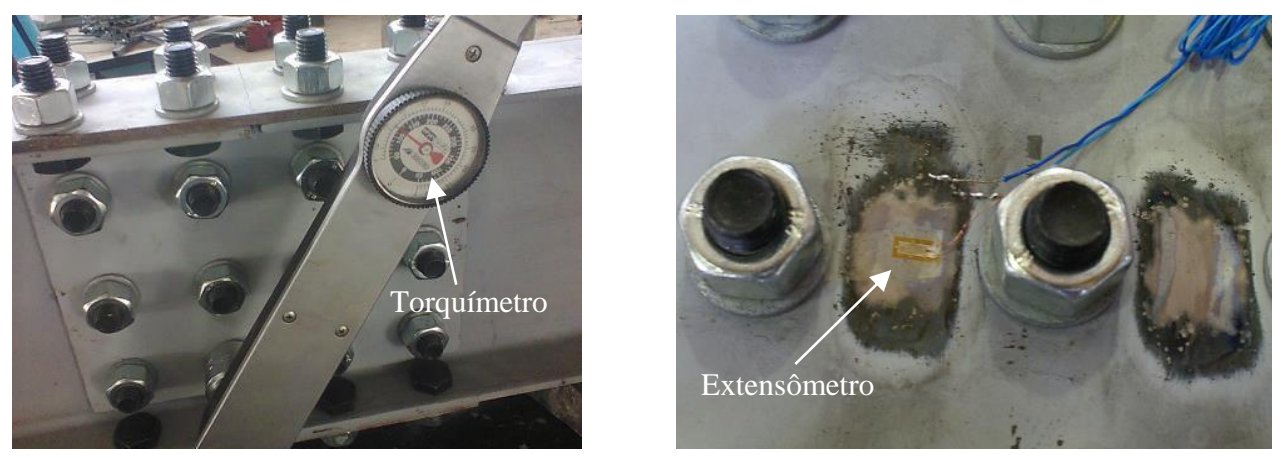

Figura 10: Preparação da viga utilizada no ensaio.

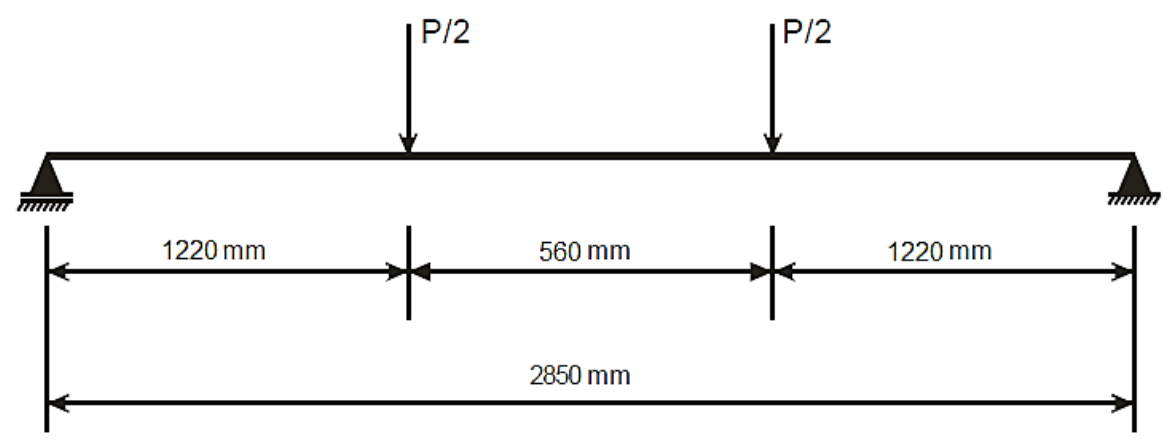

Figura 11: Esquema de aplicação das forças. Fonte: Almeida (2009). 
As vigas foram posicionadas sobre aparelhos de apoio formados por chapas metálicas e cilindros de aço. A Figura 12 descreve uma viga simplesmente apoiada. $\mathrm{O}$ apoio tipo (a) simula um apoio do 10 gênero, o qual permite deslocamento horizontal e rotação em torno do eixo longitudinal do cilindro de apoio, enquanto o apoio tipo (b) simula um apoio do 20 gênero, restringindo os deslocamentos e permitindo a rotação em torno do eixo longitudinal do cilindro de apoio. Estes aparelhos de apoio foram posicionados sobre blocos rígidos.

Foi utilizada uma viga de transição apoiada sobre a viga ensaiada, isto para obter uma divisão no valor da força $\mathrm{P}$ aplicada em duas forças iguais a $\mathrm{P} / 2$ como mostra na Figura 13. A Figura 14 demonstra todo o aparato experimental.

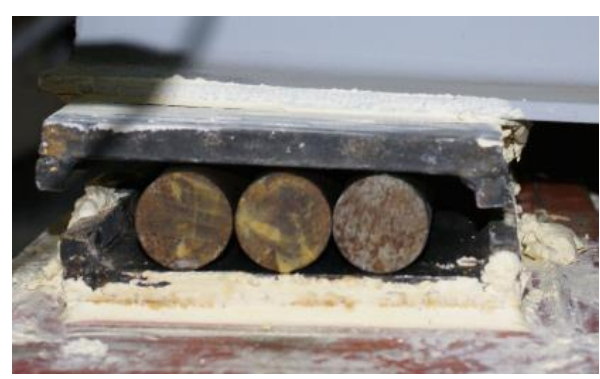

a) Apoio de 1 을ero

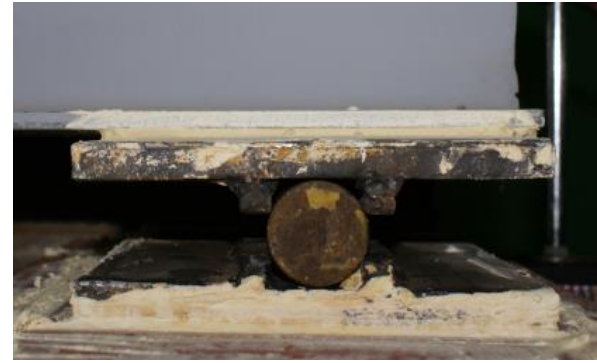

b) Apoio de 2oênero

Figura 12: Apoios de primeiro e segundo gênero.

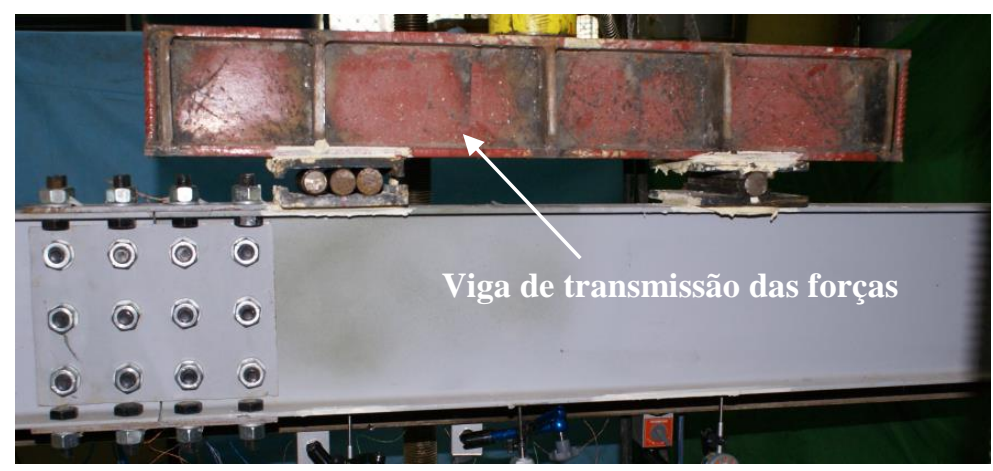

Figura 13: Viga de transmissão das forças apoiada sobre a viga ensaiada.

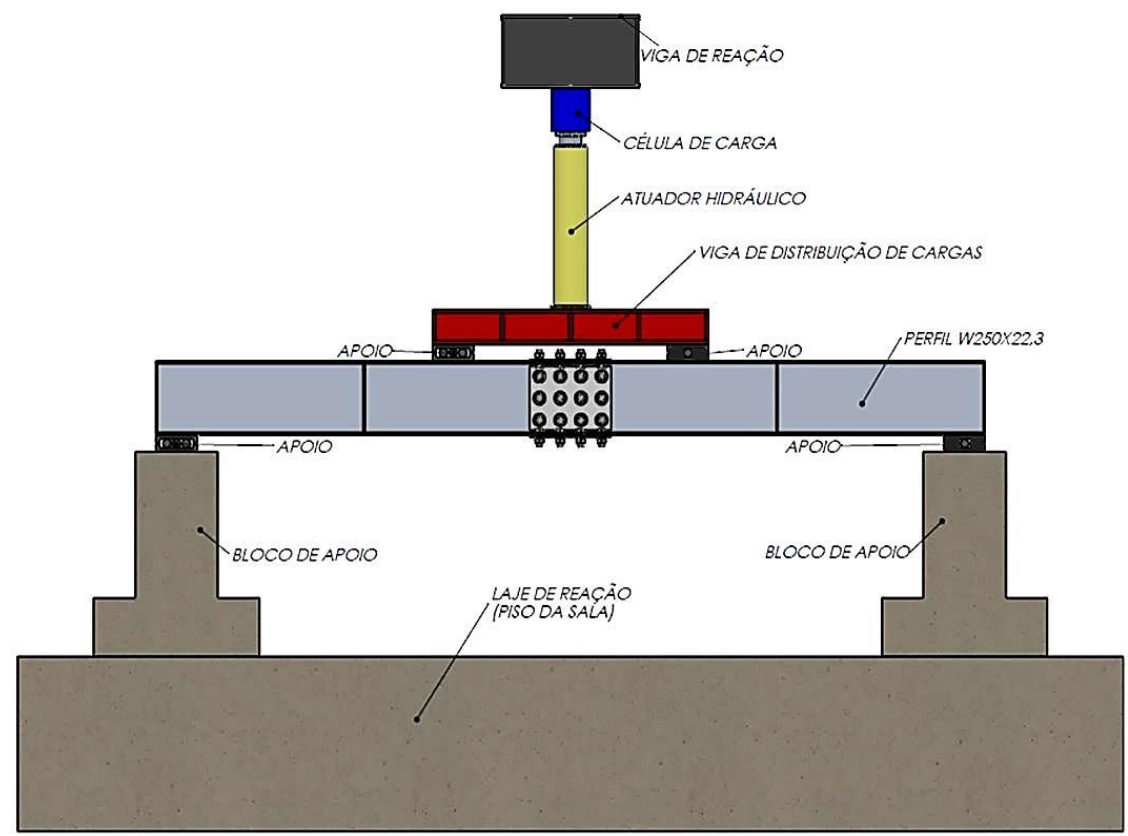

Figura 14: Ilustração do esquema montado para o ensaio de viga. 
Para a medição dos deslocamentos verticais foram utilizados cinco deflectômetros da marca Mytutoyo com sensibilidade de 0,01 mm, posicionados ao longo da viga em posições prédeterminadas. $\mathrm{O}$ carregamento foi aplicado com a ajuda de atuador hidráulico da marca Yellow Power com capacidade de 500 kN, e sua intensidade foi verificada por uma célula de carga posicionada entre o atuador hidráulico e a viga de reação.

O método de montagem do ensaio é dividido na seguinte sequência de etapas: instalação dos aparelhos de apoio, posicionamento da viga, instalação dos aparelhos de apoio da viga de transmissão, posicionamento da viga de transmissão, posicionamento do atuador hidráulico, posicionamento da célula de carga, verificação do prumo; marcação e posicionamento dos aparelhos medidores.

Foram fixadas as chapas metálicas e os aparelhos de apoios com gesso tipo alfa de alta resistência mecânica a fim de garantir que as chapas metálicas ficassem niveladas para o posicionamento das vigas. Após a cura do gesso pedra, a viga foi transportada manualmente até o local de execução dos ensaios, sendo posicionada previamente sobre os apoios. Em seguida posicionaram-se as chapas metálicas que apoiam a viga de transmissão das forças e sobre a viga de transmissão posicionou-se o atuador hidráulico no centro da viga.

Para um melhor posicionamento da célula de carga foi colocado uma chapa metálica sobre o atuador hidráulico e sobre a célula de carga. Com isso o esquema de ensaio foi travado para a montagem dos aparelhos de medição.

As vigas foram fixadas com a excentricidade, nível e prumo, foi feita a marcação e instalação dos relógios, LVDT's. Os extensômetros foram conectados ao aparelho transdutor e ao computador, sendo realizada uma leitura teste de todos os equipamentos de medição.
O início do ensaio foi executado observando um passo de carga previamente estabelecido de 2,5 kN. A cada execução do devido passo de carga foi anotada a carga atuante, a leitura dos extensômetros através do computador e as leituras dos deflectômetros foram registradas em uma planilha até o término do ensaio.

O procedimento foi monitorado por meio de comparações das leituras através do uso de planilhas, de forma que quando as peças alcançavam um nível de deformação considerado próximo à ruptura, os relógios eram retirados para preservação dos equipamentos.

\section{RESULTADOS E DISCUSSÃO}

\subsection{ENSAIOS DE TRAÇÃO}

Nos ensaios à tração dos corpos de prova de aço da mesa do perfil, a tensão limite de ruptura à tração fu consistiu de 493,49 MPa, sendo uma maior tensão obtida em relação aos outros corpos de prova que foram de 491,87 MPa para os corpos de prova de aço da alma e 440,69 MPa para os corpos de prova de aço da ligação. Os corpos de prova dos parafusos tiveram uma tensão de ruptura à tração fu de 645,98 MPa.

\subsection{DESLOCAMENTOS VERTICAIS}

Os deslocamentos verticais, conforme descritos anteriormente foram medidos por deflectômetros posicionados na mesa inferior da viga (R2/R4) sob os pontos de aplicação das forças, no meio do vão (R3) e a $600 \mathrm{~mm}$ do apoio da direita na mesa superior da viga (R1) e $600 \mathrm{~mm}$ do apoio da esquerda na mesa superior da viga (R5) a carga de retirada dos relógios foi indicada por $\mathrm{Pu}$ lei enquanto a carga de ruptura foi dada por Pu.

Os deslocamentos verticais são exibidos nas Figuras 15 a 18. 


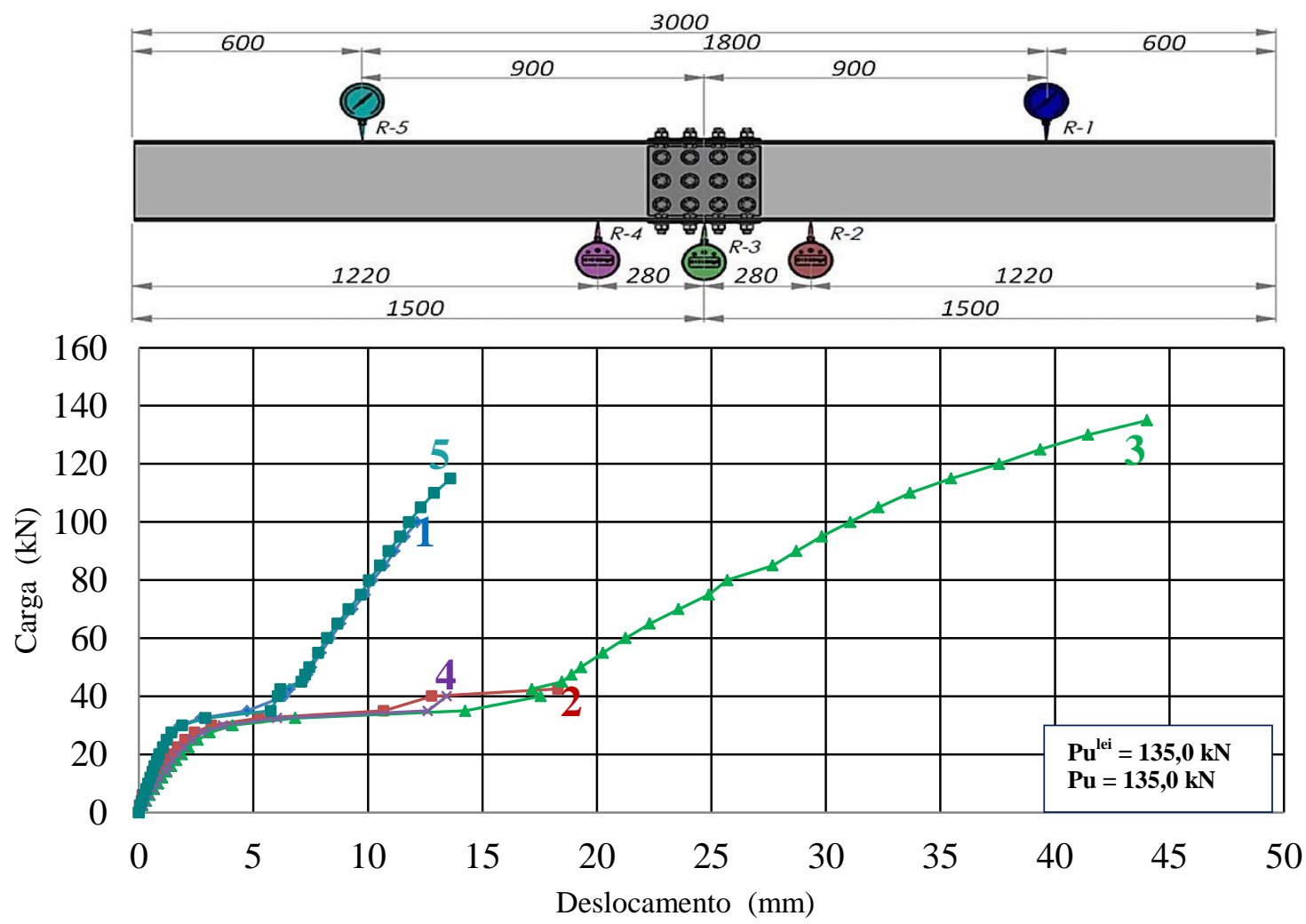

Figura 15: Deslocamentos verticais VI-1/2SE.

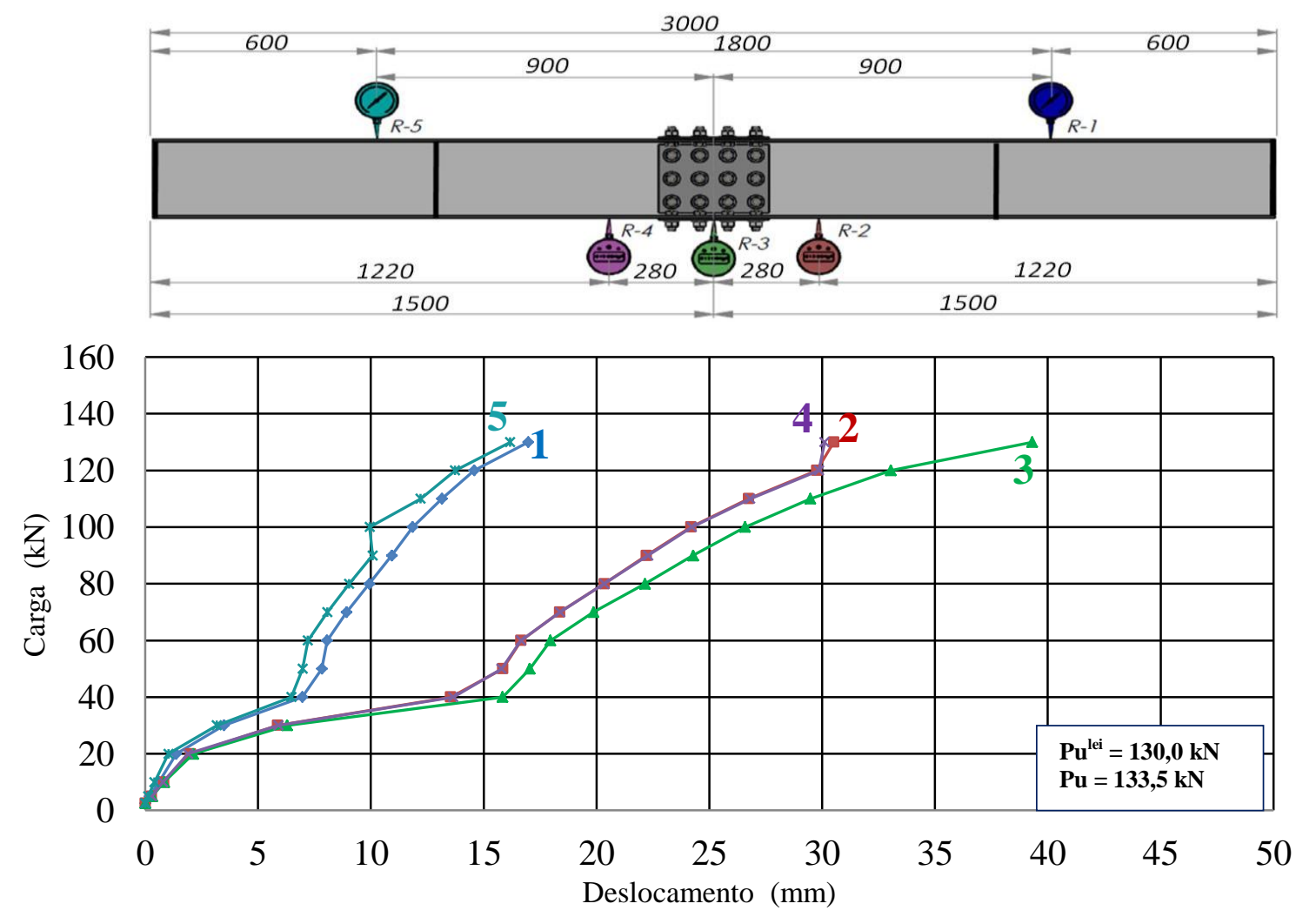

Figura 16: Deslocamentos verticais VI-1/2CE. 

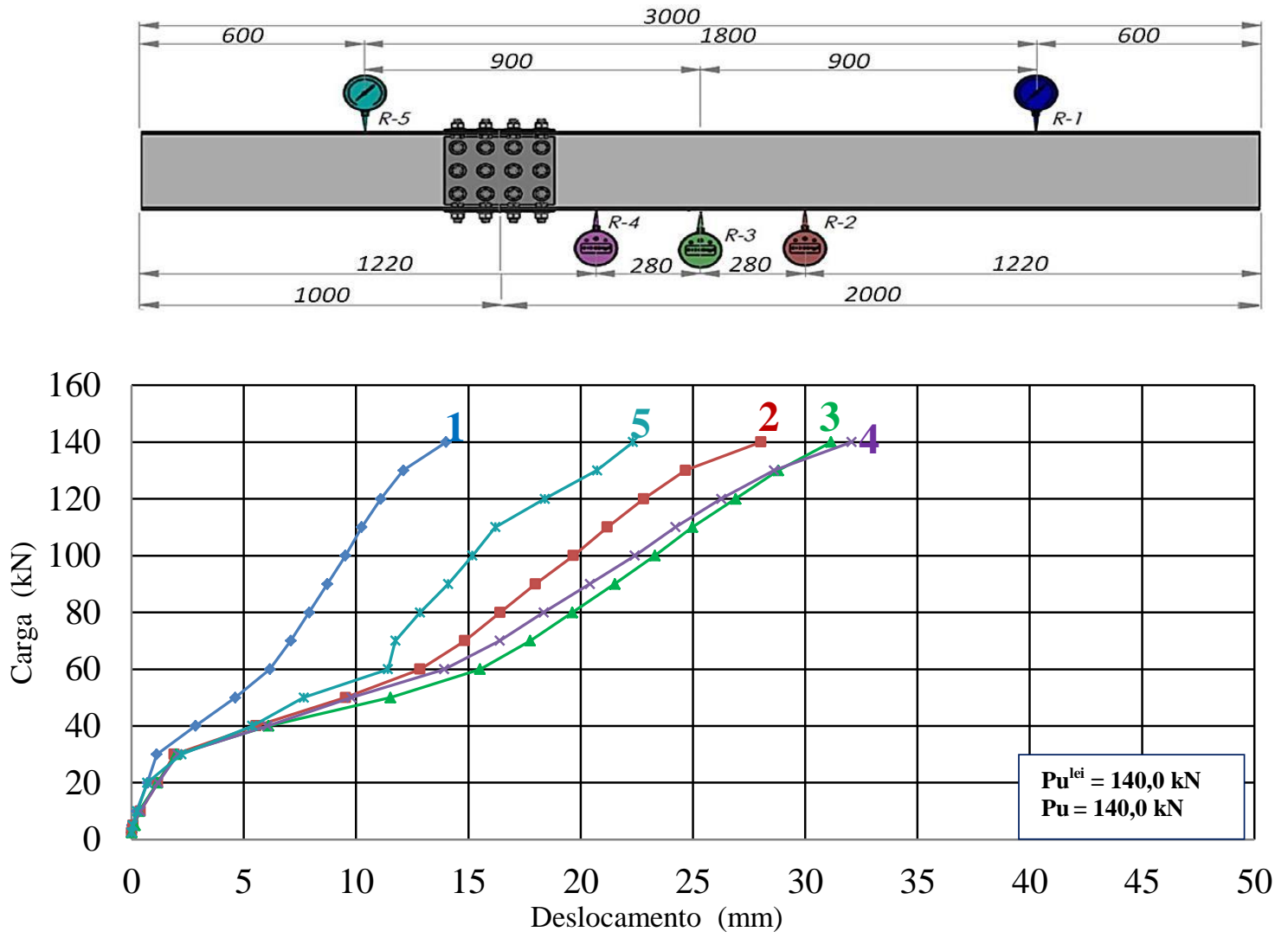

Figura 17: Deslocamentos verticais VI-1/3E.

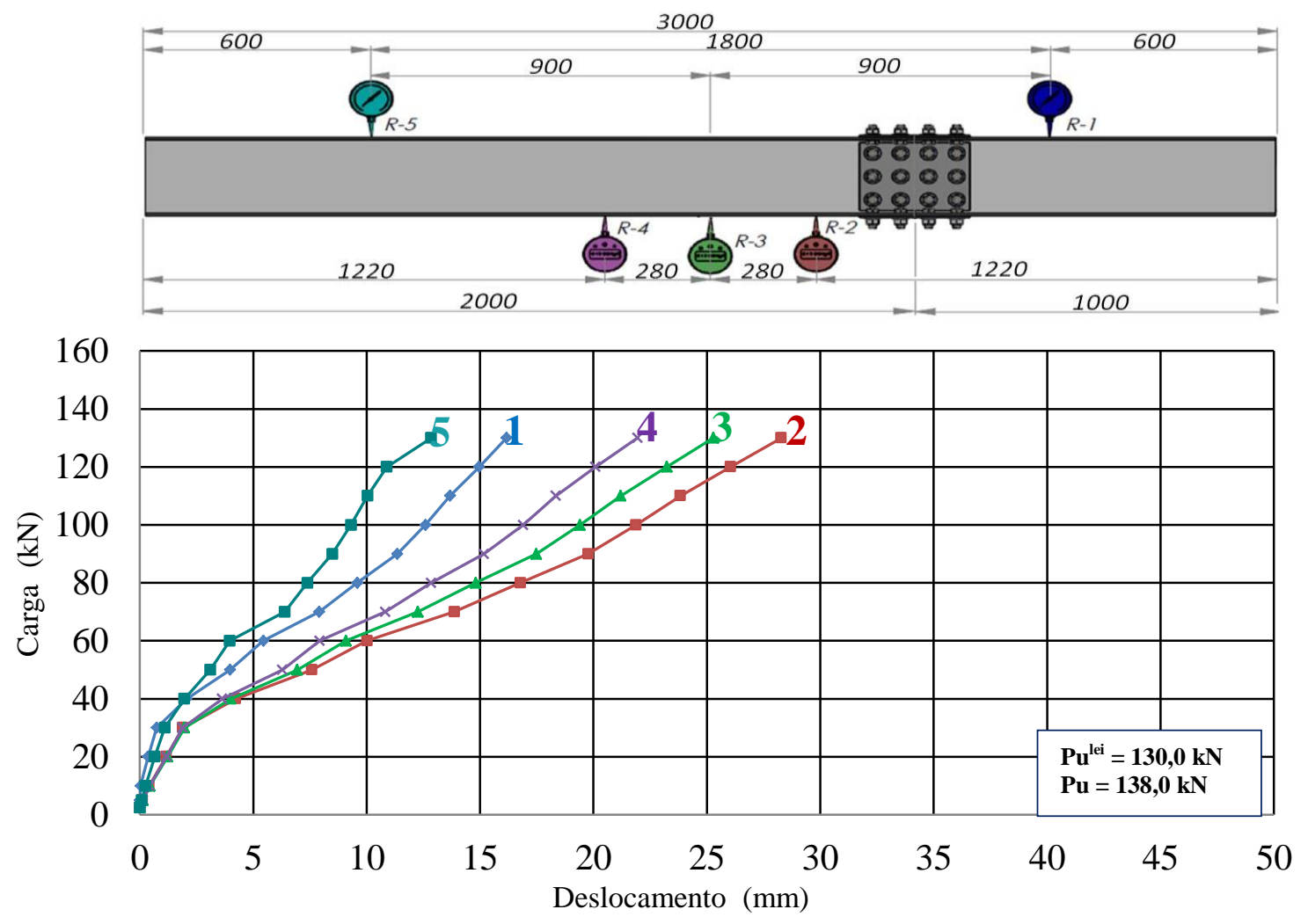

Figura 18: Deslocamentos verticais VI-1/3D. 
Para mostrar que existe eficiência no posicionamento das vigas e uma excentricidade requerida, os relógios R1 e R5 posicionados simetricamente na mesa comprimida e os relógios R2 e R4 também posicionados simetricamente na mesa tracionada, apresentaram em todos os casos comportamento simétrico ou bem próximo da simetria, principalmente nas vigas com emendas no meio do vão.

As vigas $\mathrm{VI}-1 / 3 \mathrm{E}$ e $\mathrm{VI}-1 / 3 \mathrm{D}$ tiveram um menor deslocamento em relação as vigas VI-1/2SE e VI-1/2CE onde se explica o fato das ligações serem a um terço dos apoios e não no meio do vão.

A Tabela 1 apresenta os resultados dos deslocamentos máximos no meio do vão obtidos pela leitura do relógio $R 3$ e dos gráficos (carga $x$ deslocamento) das vigas VI-1/2SE e VI-1/2CE com ligação no meio.

Analisando o deslocamento vertical das vigas no relógio $\mathrm{R} 3$, observou-se que a viga $\mathrm{VI}-1 / 2 \mathrm{SE}$ teve o maior deslocamento, pois se trata de uma viga que não contém enrijecedor, isto comparando com a viga $\mathrm{VI}-1 / 2 \mathrm{CE}$ que tem ligação no meio da viga e contém enrijecedor,

As vigas $\mathrm{VI}-1 / 3 \mathrm{E}$ e $\mathrm{VI}-1 / 3 \mathrm{D}$ obtiveram um menor deslocamento vertical onde justifica-se $\mathrm{o}$ fato de não ter ligação no meio do vão e sim a um terço dos apoios. A viga VI-1/3E proporcionou um valor máximo de deslocamento no relógio $\mathrm{R} 4$ de $32,06 \mathrm{~mm}$ e a viga VI-1/3D apresentou um valor de deslocamento máximo no relógio $\mathrm{R} 2$ de $28,28 \mathrm{~mm}$.

A Figura 19 apresenta resultados de comparação de deslocamentos verticais dos relógios $\mathrm{R} 3$ de todas as vigas.

\section{Tabela 1: Deslocamento máximo do R3.}

VIGA

Deslocamento máximo no meio do vão $(\mathrm{mm})$

\begin{tabular}{lc}
\hline $\mathrm{VI}-1 / 2 \mathrm{SE}$ & 44,03 \\
$\mathrm{VI}-1 / 2 \mathrm{CE}$ & 39,31 \\
\hline
\end{tabular}

3000
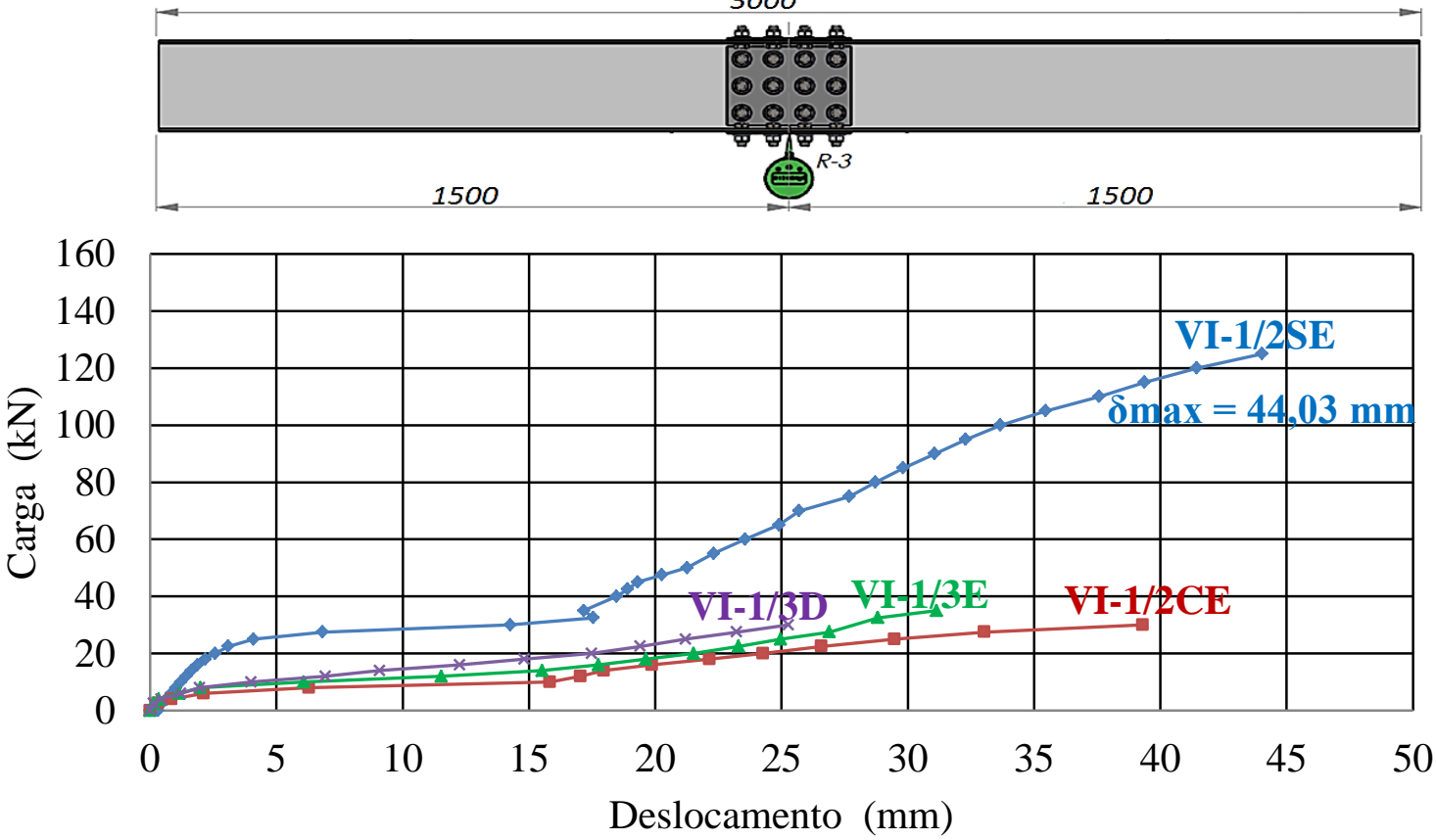

Figura 19: Deslocamento do relógio R3 de todas as vigas. 


\subsection{CARGAS E MODO DE RUPTURA}

As vigas com ligações parafusadas apresentaram um bom comportamento em suas emendas, pois não mostraram nenhum modo de ruptura em parafusos de forma que comprometesse as ligações.

O modo de falha previsto para todas as vigas ensaiadas consistiu em flambagem lateral por torção (FLT), mas todas as vigas também apresentaram flambagem local da mesa comprimida (FLM).
A flambagem local da mesa é um modo de falha onde a viga perde sua posição original e não mais pode ser carregado, caracterizando a sua ruína como consequência. No caso de estado limite último de $F L T$, o deslocamento lateral e o giro excessivos são tomados como limites para o fim do carregamento, chegando ao valor da carga de ruptura (Pu). Os modos de rupturas e carga de ruptura de todas as vigas ensaiadas são mostrados nas Figuras 20 a 23.

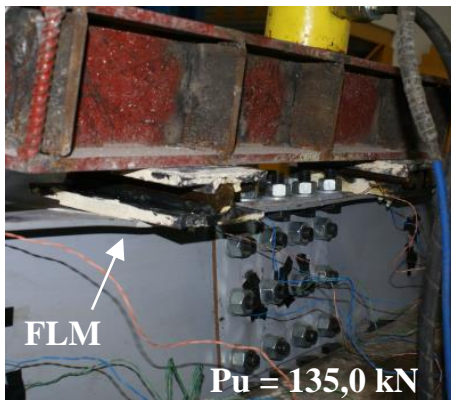

Figura 20: Modos de ruptura e carga de ruptura da viga VI-1/2SE.
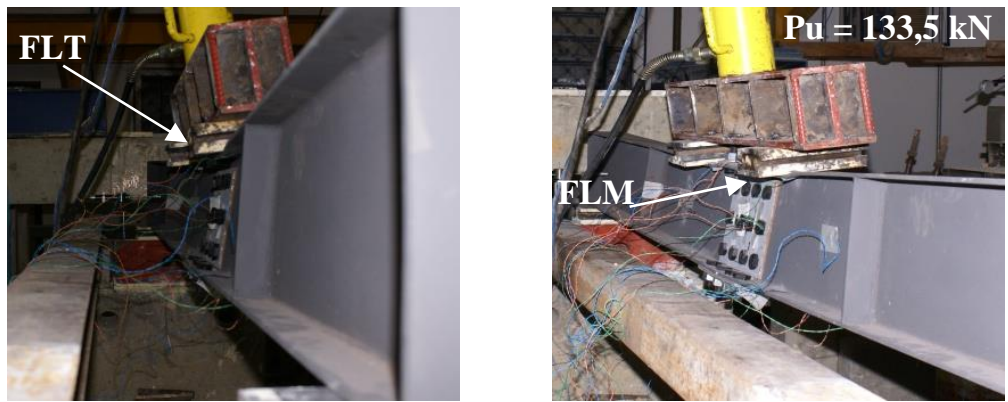

Figura 21: Modos de ruptura e carga de ruptura da viga VI-1/2CE.
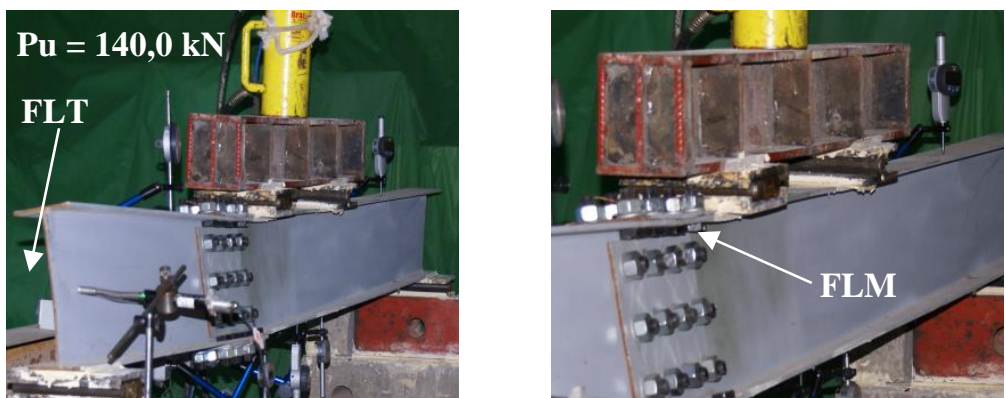

Figura 22: Modos de ruptura e carga de ruptura da viga VI-1/3E.
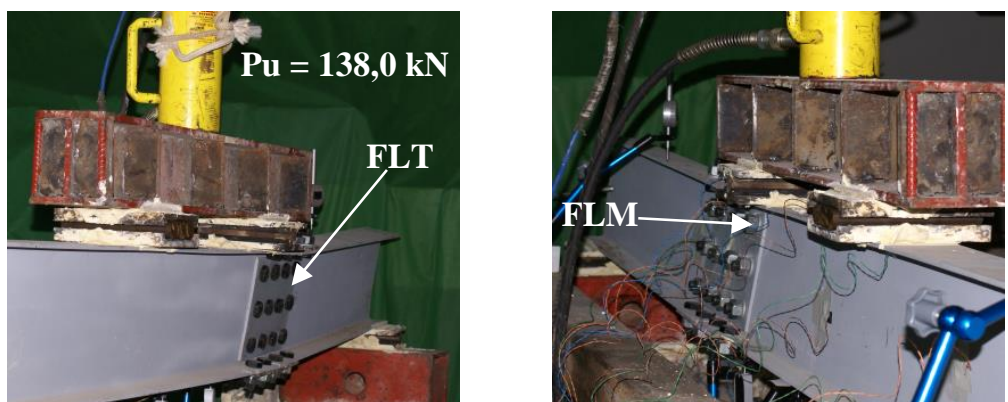

Figura 23: Modos de ruptura e carga de ruptura da viga VI-1/3D. 


\section{CONCLUSÕES}

Todas as ligações das vigas resistiram ao ensaio à flexão, não obtendo nenhuma ruptura nos parafusos e nem na chapa de ligação, e sim apresentando uma carga de ruptura das vigas bem próxima uma da outra mesmo comparando-se os valores de uma viga com contenção lateral nos apoios e a $750 \mathrm{~mm}$ dos apoios.

A viga com ligação a um terço do apoio da esquerda, viga $\mathrm{VI}-1 / 3 \mathrm{E}$, obteve uma maior carga de ruptura, porém apresentou maior flambagem lateral por torção, e torceu inversamente as outras três vigas.

As vigas $\mathrm{VI}-1 / 2 \mathrm{SE}$ e $\mathrm{VI}-1 / 2 \mathrm{CE}$ tiveram um escorregamento da chapa de ligação maior do que as vigas $\mathrm{VI}-1 / 3 \mathrm{E}$ e $\mathrm{VI}-1 / 3 \mathrm{D}$, este escorregamento aconteceu no início do carregamento.

A flambagem local da mesa comprimida em todas as vigas mostrou um empenamento da chapa da mesa principalmente onde às reações eram aplicadas, e sempre empenaram no sentido de giro que a viga obteve por flambagem lateral por torção.

As vigas com ligações parafusadas apresentaram um bom comportamento em suas emendas, pois não mostraram nenhum modo de ruptura em parafusos de forma que comprometesse as ligações.

Em relação aos deslocamentos verticais, a viga com uma emenda central apresentou um deslocamento maior que as outras vigas da série para um mesmo carregamento.

\section{AGRADECIMENTOS}

À coordenação de aperfeiçoamento de pessoal de nível superior - Capes, Metal Eng. pela colaboração na confecção dos modelos ensaiados e a Pontifícia Universidade Católica de Goiás pelos ensaios de corpo de prova.

\section{REFERÊNCIAS BIBLIOGRÁFICAS}

ABNT: Associação Brasileira de Normas Técnicas. NBR 6152 : 2002 - Materiais metálicos - Ensaio de tração à temperatura ambiente - Procedimento. Rio de Janeiro, 2002.
ABNT: Associação Brasileira de Normas Técnicas. NBR 7007:2011 - Aço carbono e microligados para uso estrutural e geral - Procedimento. Rio de Janeiro, 2011.

ABNT: Associação Brasileira de Normas Técnicas. NBR 8800:2008 - Projeto de estruturas de aço e de estruturas mistas de aço e concreto de edifícios Procedimento. Rio de Janeiro, 2008.

ALMEIDA, A. F. Análise Experimental de Vigas Constituídas de Perfis Formado a Frio com Emendas Soldadas Submetida à Flexão Simples. Dissertação (Mestrado), UFG, Goiânia, Goiás, 2009.

ASTM: AMERICAN SOCIETY FOR TESTING AND MATERIALS. Standard Specification for HighStrength Low-Alloy Columbium-Vanadium Structural Steel. ASTM A 572 / A 572M, West Conshohocken, 2006.

GOMES, C. A. B. Resistência à compressão de perfis H laminados de abas paralelas. Dissertação (Mestrado), UFOP, Ouro Preto, Minas Gerais, 2006.

PFEIL, W.; PFEIL, M. Estruturas de aço: dimensionamento prático. 8.ed. Rio de Janeiro, LTC, 2009.

RCSC: Research Council on Structural Connections. Specification for Structural Joints Using HighStrength Bolts, Chicago, 2009.

SILVA, A. C. Estudo de Ligações Parafusadas em Perfis Formados a Frio. Dissertação (Mestrado), UFOP, Ouro Preto, Minas Gerais, 2006.

VALENCIANI, V. C. Ligações em Estruturas de Aço. Dissertação (Mestrado), USP, São Carlos, São Paulo, 1997. 